\title{
Amelioration Effect of LED Lighting in the Bioactive Compounds Synthesis during Carrot Sprouting
}

\author{
Lorena Martínez-Zamora $^{1,2}$ (D) Noelia Castillejo ${ }^{1,2}$, Perla A. Gómez ${ }^{2}$ and Francisco Artés-Hernández ${ }^{1,2, *(\mathbb{D})}$ \\ 1 Postharvest and Refrigeration Group, Department of Agronomical Engineering, Universidad Politécnica de \\ Cartagena, Paseo Alfonso XIII, 48, 30203 Cartagena, Murcia, Spain; lorena.martinez@upct.es (L.M.-Z.); \\ noelia.castillejo@upct.es (N.C.) \\ 2 Institute of Plant Biotechnology, Universidad Politécnica de Cartagena, 30202 Cartagena, Murcia, Spain; \\ perla.gomez@upct.es \\ * Correspondence: fr.artes-hdez@upct.es; Tel.: +34-968-325509
}

check for updates

Citation: Martínez-Zamora, L.; Castillejo, N.; Gómez, P.A.;

Artés-Hernández, F. Amelioration

Effect of LED Lighting in the

Bioactive Compounds Synthesis during Carrot Sprouting. Agronomy 2021, 11, 304. https://doi.org/ 10.3390/agronomy11020304

Academic Editors: Youssef Rouphael, Giuseppe Colla and Stefania De Pascale

Received: 11 January 2021

Accepted: 3 February 2021

Published: 9 February 2021

Publisher's Note: MDPI stays neutral with regard to jurisdictional claims in published maps and institutional affiliations.

Copyright: (c) 2021 by the authors. Licensee MDPI, Basel, Switzerland. This article is an open access article distributed under the terms and conditions of the Creative Commons Attribution (CC BY) license (https:// creativecommons.org/licenses/by/ $4.0 /)$.
Abstract: Background: This work investigates the morphological and compositional changes of carrots sprouts during 17 days at $20^{\circ} \mathrm{C}$. Methods: Growing conditions were 7 days in darkness (dD) followed by 3,7 , or 10 days of a $16 \mathrm{~h}$ light $/ 8 \mathrm{~h}$ darkness photoperiod (dP). Light stimuli used were fluorescent light $(\mathrm{Fl})$, Blue+Red $(\mathrm{B}+\mathrm{R})$, Blue+Red+Far-Red $(\mathrm{B}+\mathrm{R}+\mathrm{FR})$ Light-Emitting DiodesLEDs- and darkness as control. Results: Results showed that lighting conditions improved the total antioxidant activity and increased the bioactive compounds compared to darkness treatment. However, hypocotyl and sprout length were increased under darkness conditions. Both LEDs treatments $(\mathrm{B}+\mathrm{R}$ and $\mathrm{B}+\mathrm{R}+\mathrm{FR}$ ) increased the phenolic content (phenolic acids and rutin) by $45 \%$ and $65 \%$ compared to darkness and by $32 \%$ regarding Fl. Moreover, a similar trend was observed in the carotenoids content under B+R LEDs, but not when FR was added. Conclusions: Our results suggest that LED lighting during carrot sprouting improved the synthesis of health-promoting compounds.

Keywords: Daucus carota L.; light-emitting diode; carotenoids; individual phenolic compounds; total scavenging activity; antioxidants

\section{Introduction}

Darkness and fluorescent lighting are widely used during sprouting and growth of different crops. Plant pigments absorb light in the visible spectrum between 400 and $700 \mathrm{~nm}$, which is typically referred to as photosynthetically active radiation (PAR). Light, both the quantity (intensity) and quality (spectrum), plays an important role in cultivation. Nowadays, the use of artificial light during growing has suggested a new way to extend the shelf-life of fruit and vegetables while improving their nutritional properties and promotes the biosynthesis of phytochemical compounds, such as phenols and carotenoids [1-3]. The influence of color light on the accumulation and biosynthesis of plant compounds has been known for years, as well as the application of abiotic stresses for enhancing the nutraceutical content of fresh fruit and vegetables [1,4]. However, researchers are just starting to discover the basic mechanisms by which light signals are transduced to modulate the growth and the production of photoprotective compounds [5].

Many authors have reported that red and blue lights are one of the most important spectral regions as they selectively activate different photoreceptors related to photosynthesis. These photoreceptors can absorb a range of light wavelengths from near ultraviolet -UV- (300-350 nm) to far-red light (700-750 nm). In fact, cryptochromes, phototropins, and Zeitlupe family proteins for blue light $(430-480 \mathrm{~nm})$ and phytochromes for red light (640-700 nm) have important roles in seed germination, plant development, flowering, leaf expansion, and biosynthesis of phytochemical compounds [6,7]. Red light has been reported to promote vegetative growth by increasing the chlorophyll content and reproductive growth [8], while blue light, being mostly absorbed by carotenoid pigments (like lutein 
and $\beta$-carotene), has also been reported to improve the photosynthetic capacity of plants [9]. Plant growth and metabolism can be optimized when multiple LEDs are combined or alternated [10]. They have a narrow-brand wavelength allowing monochromatic lights with different intensities. In these facts lie the efficiency and versatility of LEDs, which, added to their low cost, are now a good alternative to replace the most common current cultivation cycle of fluorescent light and darkness.

Sprouts and microgreens are valued as functional foods because of their greater concentrations of nutraceutical compounds as compared to the adult plant [11,12]. For this reason, plants during the first steps of their germination and growth show relevant health benefits for the consumer concerned about a healthy lifestyle. Specifically, Nam et al. [13] have reported an improvement by $10 \%$ the total phenolic content and $12 \%$ the total flavonoid content of common buckwheat sprouts after 7 days of sprouting under a 16 $\mathrm{h}$ blue light $/ 8 \mathrm{~h}$ darkness daily photoperiod. Seo et al. [14] showed an increase of $465 \%$ of anthocyanin content after 11 days of sprouting under the same photoperiod.

Although the bibliography on this topic is extensive, no previous reports have studied the influence of these lights on development of carrot sprouts, selected as a plant-model with high carotenoid content. Carrot (Daucus carota L.) is a root vegetable, well-known as an important source of dietary fiber and natural antioxidants, including carotenoids, vitamins, minerals, and phenolic compounds [15,16]. These bioactive compounds act as free radical scavengers and inhibitors of prooxidative enzymes or external agents. In fact, carrot roots contain abundant biologically active substances which play important roles in preventing diseases through the diet $[15,16]$.

Therefore, the aim of the present study was to evaluate the morphological development and the bioactive compounds synthesis (carotenoids and phenolics) during 7 days of Darkness $(\mathrm{dD})+\mathrm{a} 10$ days Photoperiod $(\mathrm{dP})$ of carrot sprouts' growth under different lighting treatments including LEDs (Blue, Red, and Far-Red) in a $16 \mathrm{~h}$ light/ $8 \mathrm{~h}$ darkness photoperiod.

\section{Materials and Methods}

\subsection{Reagents}

Folin-Ciocalteu reagent, DPPH (2,2-diphenyl-1-picrylhydrazyl), ABTS (2,2'-azinobis(3-ethylbenzothiazoline-6-sulfonic acid)), and TPTZ (2,4,6-Tris(2-pyridyl)-s-triazine) were purchased from Merck (Sigma, Darmstadt, Germany). Sodium carbonate $\left(\mathrm{Na}_{2} \mathrm{CO}_{3}\right)$, sodium hydroxide $(\mathrm{NaOH})$, sodium chloride $(\mathrm{NaCl})$, and chlorogenic acid, caffeic acid, p-coumaric acid, ferulic acid, hydroxycinnamic acid, and rutin standards were purchased from Merck (Sigma, Darmstadt, Germany). Trolox (6-hydroxy-2,5,7,8-tetramethylchroman2-carboxylic acid), chlorogenic acid (5-caffeoylquinic acid), $\beta$-carotene, and lutein standards were purchased from Merck (Sigma, Darmstadt, Germany). Tert-methyl butyl ether (MTBE), methanol, chloroform, dichloromethane, and phosphoric acid were purchased from Panreac (Barcelona, Spain). All reagents were High Performance Liquid Chromatography (HPLC) grade. Milli-Q water was obtained from a water purification system (Millipore, Merck, Darmstadt, Germany).

\subsection{Plant Material and Sprouting Conditions}

Carrot (Daucus carota L.) seeds were provided by Intersemillas S.A. (Valencia, Spain). The weight of 100 seeds was $0.11 \pm 0.00 \mathrm{~g}$. Two $\mathrm{g}$ of carrot seeds ( 909 seeds $\mathrm{g}^{-1}$ ) were soaked in distilled water overnight at room temperature. Then, they were transferred into sterilized polypropylene trays $(173 \times 120 \times 80 \mathrm{~mm}$; $1500 \mathrm{~mL})$ with water-moistened filter paper on the bottom. Seeds were germinated in a plant growth chamber (Sanyo MLR-350 $\mathrm{H}$, Osaka, Japan) under darkness conditions for 7 days (7 dD) at $20{ }^{\circ} \mathrm{C}$ and $90 \%$ Relative Humidity (RH). After that period, the sprouts were exposed to daily cycles of $16 \mathrm{~h}$ light $/ 8 \mathrm{~h}$ darkness photoperiod (dP). Each replicate was a tray, and each sample was composed of five replicates. 


\subsection{Light Treatments Used during the Photoperiod}

Light treatments assayed during the photoperiod were: $\mathrm{Fl}$ (fluorescent), $\mathrm{B}+\mathrm{R}$ (Blue+Red), and $\mathrm{B}+\mathrm{R}+\mathrm{FR}$ (Blue+Red+Far-Red) LED lamps, while darkness was used as a control. LED lamps used in the trial were provided by LEDMurcia S.L. (Murcia, Spain): Blue (B; peak at $450 \mathrm{~nm}$ ), Deep-Red (R: $660 \mathrm{~nm}$ ), and Far-Red (FR; peak at $730 \mathrm{~nm}$ ). Fl lighting was provided by fluorescent lamps with white spectrum (Philips 36W/54-765) during the photoperiod $\left(2016 \mathrm{~kJ} \mathrm{~m}^{-2}\right)$. When applying LED illumination, the majority of the published works deal with a simultaneous combination of LEDs. However, there are few studies reporting the effect of an alternation of the LED lights. In fact, Ohtake et al. [10] reported that an alternation of $12 \mathrm{~h}$ red and $4 \mathrm{~h}$ blue lights (Red/Blue ratio $=3$ ) improved the plant growth and enhanced the nutritional quality of lettuce compared to a simultaneous combination of the same LED lights. However, no other works studied such effect during seed sprouting. Therefore, we assayed such light combinations during carrot sprouting. For B+R treatment, the ratio of 3 was achieved by switching the $B$ light on for $4 \mathrm{~h}$ followed by $\mathrm{R}$ LEDs for $12 \mathrm{~h}\left(2073.74 \mathrm{~kJ} \mathrm{~m}^{-2}\right)$. For B+R+FR LED lighting, B LEDs were switched on for $3 \mathrm{~h} 31 \mathrm{~min}$ followed by R LEDs for $10 \mathrm{~h} 24 \mathrm{~min}$ and FR LEDs for $2 \mathrm{~h} 5 \mathrm{~min}\left(2361.8 \mathrm{~kJ} \mathrm{~m}^{-2}\right)$. R+B and $\mathrm{R}+\mathrm{B}+\mathrm{FR}$ ratios were calculated by comparing the area under the curve of the spectral regions in the B (440-455 nm), R (650-670 nm), and the FR (720-740 nm). Spectral properties were determined using an illuminance spectrophotometer (CAS 140CT, Instrument Systems, Konica Minolta Group, Munich, Germany). A constant PPF (photosynthetic photon flux) for $\mathrm{Fl}, \mathrm{B}+\mathrm{R}$, and $\mathrm{B}+\mathrm{R}+\mathrm{FR}$ of 168,173 , and $197 \mu \mathrm{mol} \mathrm{m}^{-2} \mathrm{~s}^{-1}$ respectively, were measured using a Quantum-Photo Radiometer Data Logger DO 9721 (Delta Ohm, S.R.L., Venice, Italy). Spectral composition of each light treatment is shown in Figure 1.

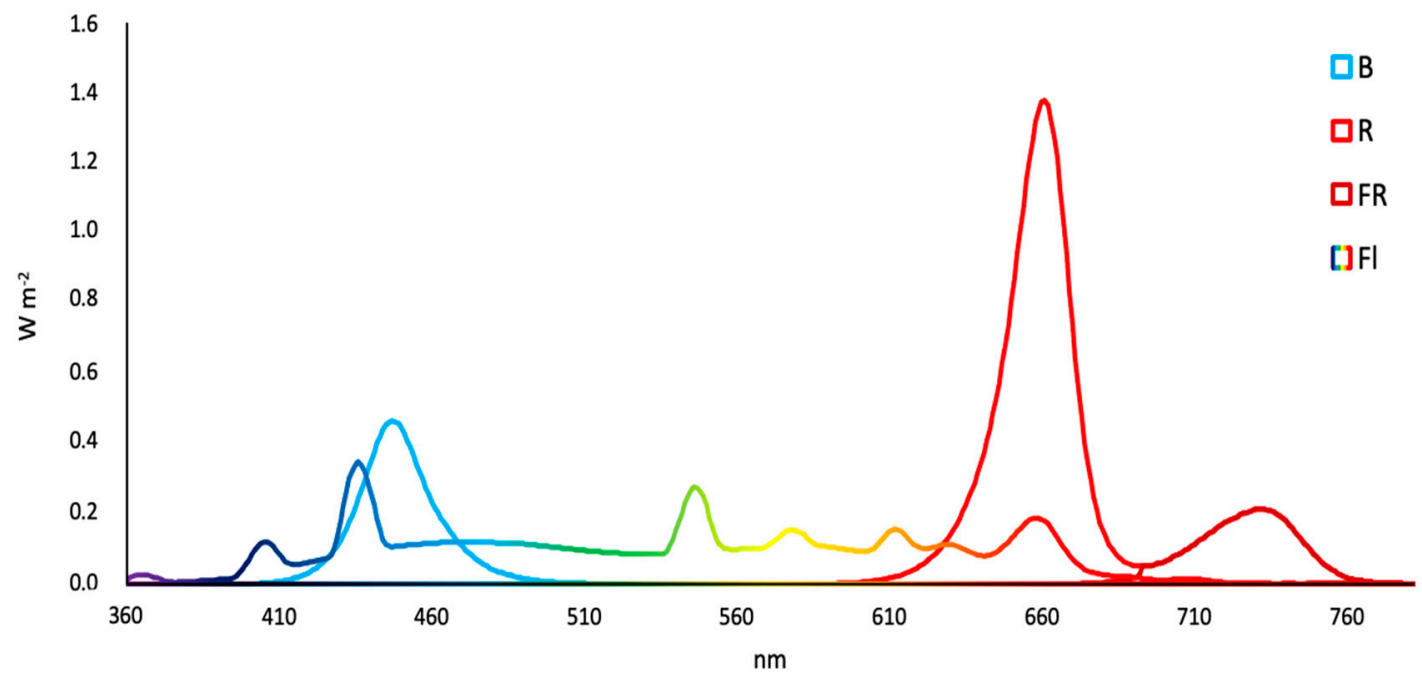

Figure 1. Spectral composition of the Blue (B), Red (R), and Far-Red (FR) light-emitting diodes (LEDs) and fluorescent light (Fl) used during carrot sprouts' growing.

Sprouts were sampled for quality analyses on days 0 (seeds), 3 ( $3 \mathrm{dD})$, and 7 (7 dD) during initial growth in darkness, and after $3(7 \mathrm{dD}+3 \mathrm{dP}), 7(7 \mathrm{dD}+7 \mathrm{dP})$, and 10 days $(7 \mathrm{dD}+10 \mathrm{dP})$ of the light/darkness photoperiod. On such days, sprouts were immediately frozen at $-80^{\circ} \mathrm{C}$ and freeze-dried by freeze dryer equipment (LyoQuest -85 , Telstar, Terrassa, Spain) and stored at room temperature until further analysis.

\subsection{Morphological Characteristics}

Morphological measurements were carried out using the software ImageJ, Version $1.52 \mathrm{v}$ for Windows. Photographs of carrot sprouts next to a ruler $(\mathrm{cm})$ were used to measure hypocotyl $(\mathrm{H})$, root $(\mathrm{R})$, and total sprout lengths $(\mathrm{H}+\mathrm{R})$. The sprout length was measured 
from root apical meristem to shoot apical meristem. H/R ratio was also calculated. Three repetitions of 15 sprouts per each treatment were measured on each sampling day.

\subsection{Extraction and Determination of Total Phenolic Content}

Twenty-five $\mathrm{mg}$ of freeze-dried samples were weighed in plastic tubes and $3 \mathrm{~mL}$ of methanol:water $(80: 20, v / v)$ was added. This mix was homogenized using an IKA A11 basic grinder (IKA, Staufen, Germany). The extraction was carried out in an orbital shaker (Stuart, Stone, UK) for $1 \mathrm{~h}$ at $200 \mathrm{rpm}$ in darkness at $4{ }^{\circ} \mathrm{C}$. The extracts were centrifuged at $3220 \times \mathrm{g}$ for $10 \mathrm{~min}$ at $4{ }^{\circ} \mathrm{C}$. The supernatant was collected and used as phenolic and total antioxidant capacity (TAC) extracts.

The total phenolic content (TPC) was determined as previously described by Singleton and Rossi [17]. Briefly, $19 \mu \mathrm{L}$ TPC extract was placed on a flat-bottom PS 96-well plate (Greiner Bio-One; Frickenhausen, Germany) and $29 \mu \mathrm{L}$ of $1 \mathrm{~mol} \mathrm{~L}^{-1}$ Folin-Ciocalteu reagent was added. After $3 \mathrm{~min}$ incubation in darkness at room temperature, $192 \mu \mathrm{L}$ of $\mathrm{Na}_{2} \mathrm{CO}_{3}(0.4 \%)$ and $\mathrm{NaOH}(2 \%)$ were added. The absorbance was measured at $750 \mathrm{~nm}$ after $1 \mathrm{~h}$ incubation at room temperature in darkness using a Multiscan plate reader (Tecan Infinite M200, Männedorf, Switzerland). The TPC was expressed as mg chlorogenic acid equivalents (CAE) $\mathrm{kg}^{-1}$ dry weight $(\mathrm{dw})$. Each sample was analyzed in triplicate.

\subsection{Individual Phenolic Content Analyses}

A sample of $1 \mathrm{~mL}$ of the extracted solution was collected and filtered using $0.2 \mu \mathrm{m}$ PTFE membrane filters. Analysis and identification of individual phenolic compounds were conducted according to Moreira-Rodríguez et al. [18]. An Ultra High-Performance Liquid Chromatography instrument (Shimadzu, Kyoto, Japan) equipped with a DGU-20A degasser, LC-30AD quaternary pump, SIL-30AC autosampler, CTO-10AS column heater, and SPDM-20A photodiode array detector was used. Chromatographic analyses were carried out into a Gemini C18 column $(250 \times 4.6 \mathrm{~mm}, 5 \mu \mathrm{m}$ particle size; Phenomenex, Torrance, CA, USA). The peaks of the chromatogram shown in Figure 2 were identified by retention time of different standards, such as chlorogenic acid, caffeic acid, p-coumaric acid, ferulic acid, hydroxycinnamic acid, and rutin. Phenolic acids were quantified as equivalents of chlorogenic acid. The results were expressed as $\mathrm{mg} \mathrm{kg}^{-1} \mathrm{dw}$. Each sample was analyzed in triplicate. 


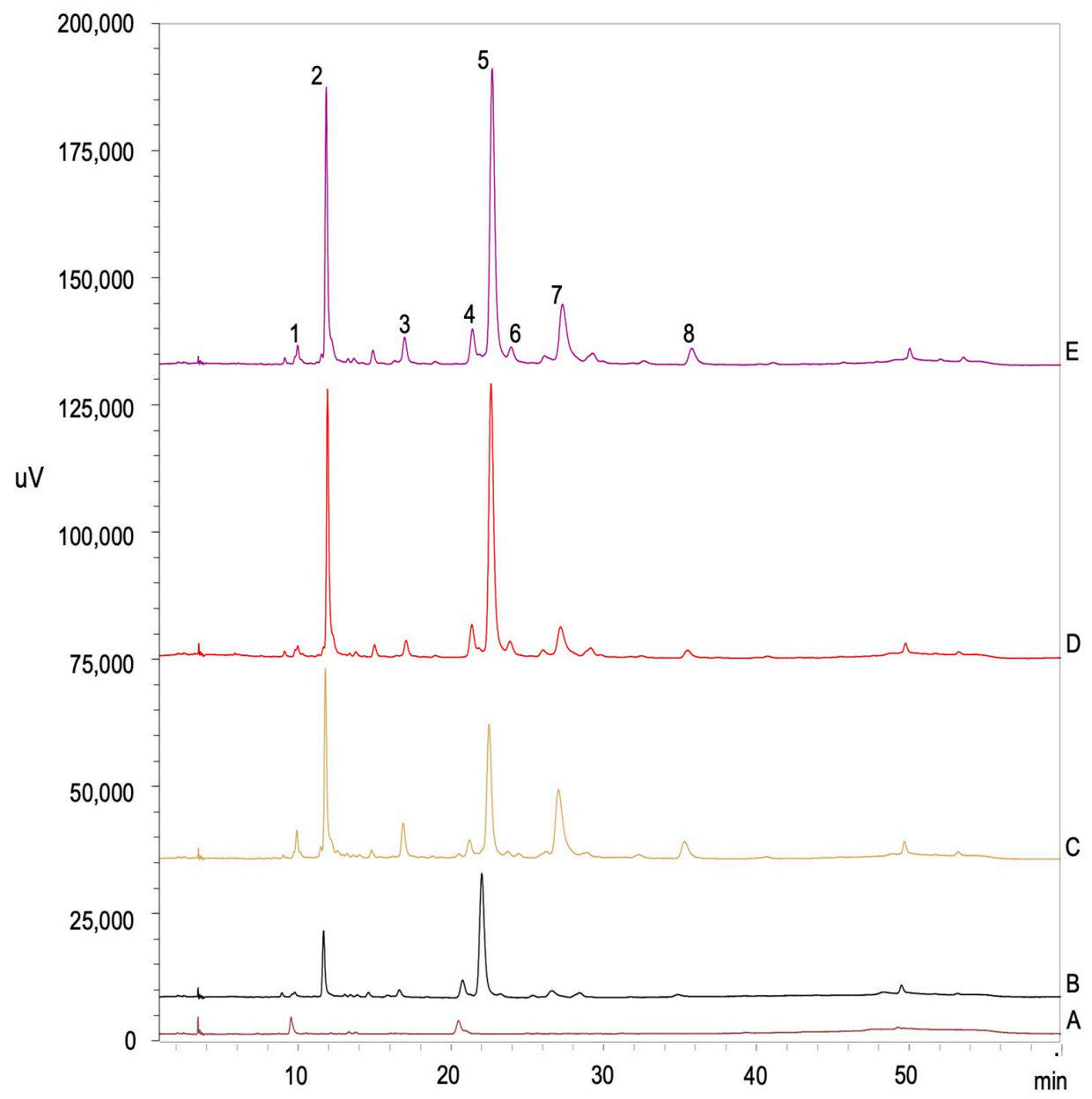

Figure 2. Ultra High Performance Liquid Cromatography (U-HPLC) chromatograms (shown at $320 \mathrm{~nm}$ ) of identified phenolic compounds from methanol/water $(80: 20, v / v)$ extracts of carrot seed $(\mathbf{A})$ and carrot sprouts on 7 days in darkness +3 days of a light/darkness photoperiod under several light treatments at $20^{\circ} \mathrm{C}$ : Darkness (B), Fluorescent (C), Blue+Red LEDs (D), and Blue+Red+Far-Red LEDs (E). Identified peaks are: Neochlorogenic Acid (1), Chlorogenic Acid (2), Caffeic Acid (3), p-coumaric Acid (4), Ferulic Acid (5), Hydroxycinnamic Acid (6), Rutin (7), and 1,2-disinapoyl-1'-ferulolylgentiobiose (8).

\subsection{Total Antioxidant Capacity}

The TAC was analyzed by three different methods: DPPH (assay used to measure the scavenging activity against DPPH generated in organic phase), FRAP (Ferric Reducing Antioxidant Power), and ABTS (to measure the scavenging capacity against ABTS generated in aqueous phase) assays. In the DPPH assay [19], $194 \mu \mathrm{L}$ of DPPH solution was added to $21 \mu \mathrm{L}$ of sprout extract in a 96-well plate. The mixture was incubated for $30 \mathrm{~min}$ at room temperature in darkness. The TAC by DPPH was measured by changes in absorbance at $515 \mathrm{~nm}$. The ABTS assay was carried out following the method previously described by Castillejo et al. [20]. For that, $200 \mu \mathrm{L}$ of the activated ABTS solution $(32 \mu \mathrm{M})$ was added to $11 \mu \mathrm{L}$ of sprout extract in a 96-well plate and incubated for $20 \mathrm{~min}$ at room temperature in darkness. The TAC by ABTS was measured by changes in absorbance at $414 \mathrm{~nm}$. In the FRAP assay [19], $198 \mu \mathrm{L}$ of the FRAP solution was added to $6 \mu \mathrm{L}$ of sprout extract in a 96-well plate and incubated for $14 \mathrm{~min}$ at room temperature in darkness. After this time, the absorbance was measured at $593 \mathrm{~nm}$. All TAC data were expressed as mg of Trolox Equivalents (TE) $\mathrm{kg}^{-1} \mathrm{dw}$. Each sample was analyzed in triplicate.

The TAC index was calculated using the equation: $\left(\mathrm{TAC}_{\mathrm{DPPH}}+\mathrm{TAC}_{\mathrm{ABTS}}+\mathrm{TAC}_{\mathrm{FRAP}}\right) / 3$. Total Scavenging Activity (\%) was calculated using the formula: (\% Scavenging ${ }_{\mathrm{DPPH}}+\%$ 
Scavenging $\left.{ }_{\mathrm{ABTS}}\right) / 2$. The radical scavenging activity of each sample against each reagent was calculated using the formula: ((Abs reagent - Abs Sample $) /$ Abs reagent $) \times 100$.

\subsection{Extraction and Analysis of Carotenoids}

Extraction and analysis of carotenoids were carried out as described by Gupta et al. [21]. For that, freeze-dried samples $(150 \mathrm{mg})$ were homogenized with $1.5 \mathrm{~mL}$ of chloroform: dichloromethane $(2: 1, v / v)$ in a basic grinder (IKA A11, Staufen, Germany). The extraction was carried out in an orbital shaker (Stuart, Stone, UK) for $20 \mathrm{~min}$ at $200 \mathrm{rpm}$ at $4{ }^{\circ} \mathrm{C}$. After this time, $0.5 \mathrm{~mL}$ of $1 \mathrm{M} \mathrm{NaCl}$ solution was added for phase separation. The extracts were centrifuged at $5000 \times g$ for $10 \mathrm{~min}$ at $4{ }^{\circ} \mathrm{C}$ and the organic phase was collected. The extracted phase was dried by centrifugal evaporation and re-dissolved in $1.2 \mathrm{~mL}$ methanol:MTBE $(60: 40, v / v)$ and filtered using $0.2 \mu \mathrm{m}$ PTFE membrane filters.

Analysis and identification of individual carotenoids were conducted according to Gupta et al. [21]. An Ultra High-Performance Liquid Chromatography (UHPLC) instrument (Shimadzu, Kyoto, Japan) equipped with a DGU-20A degasser, LC-30AD quaternary pump, SIL-30AC autosampler, CTO-10AS column heater, and SPDM-20A photodiode array detector was used. Chromatographic analyses were carried out into a C30 column $(250 \times 4.6 \mathrm{~mm}, 3 \mu \mathrm{m}$ particle size; YMC Co., Kyoto, Japan). The peaks of the chromatogram shown in Figure 3 were identified by absorption spectra of different individual carotenoids (different absorption spectra of each peak are included in the Supplementary Figure S1). Carotenoids were quantified as equivalents of $\beta$-carotene and trans-lutein. The results were expressed as $\mathrm{mg} \mathrm{kg}^{-1} \mathrm{dw}$. Each sample was analyzed in triplicate.

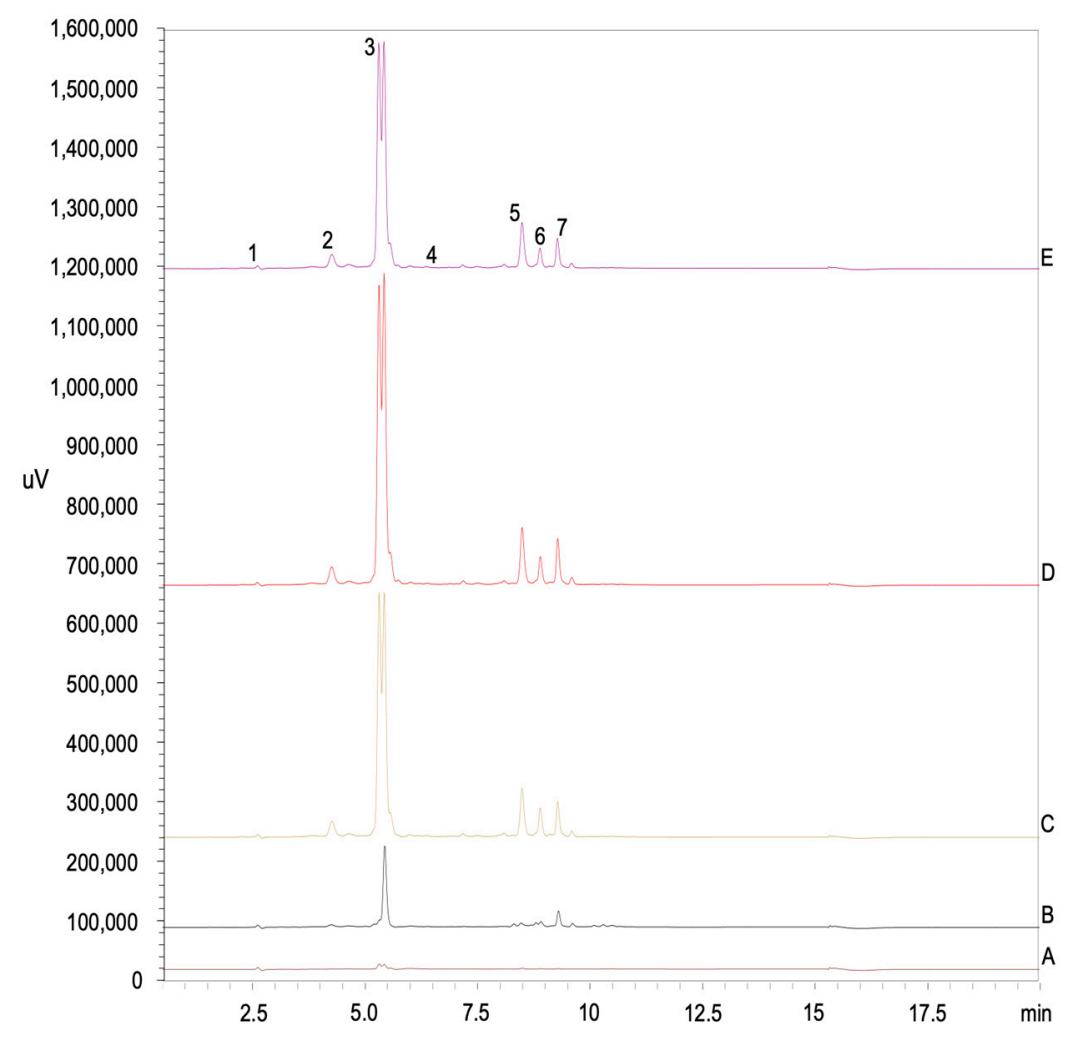

Figure 3. U-HPLC chromatograms (shown at $476 \mathrm{~nm}$ ) of identified carotenoids from methanol/MTBE $(60: 40, v / v)$ extracts of carrot seed (A) and carrot sprouts on 7 days in darkness +3 days of a light/darkness photoperiod under several light treatments at $20{ }^{\circ} \mathrm{C}$ : Darkness (B), Fluorescent (C), Blue+Red LEDs (D), and Blue+Red+Far-Red LEDs (E). Identified peaks are: All-trans neoxanthin (1), 13-cis or $13^{\prime}$-cis lutein (2), All-trans lutein (3), 9-cis or $9^{\prime}$-cis lutein (4), 15-cis $\beta$-carotene (5), All-trans $\beta$-carotene (6), and 9-cis $\beta$-carotene (7). 


\subsection{Statistical Analyses}

The experiment was a two-factor (treatment $x$ time) design subjected to analysis of variance (ANOVA) using Statgraphics Plus software (v. 5.1. Statpoint Technologies. Inc. Warrenton, VA, USA). Statistical significance was assessed at the level $p<0.05$, and Tukey's multiple range test was used to separate means.

\section{Results}

\subsection{Morphological Characteristics of Carrot Sprouts}

Table 1 shows the morphological development of carrot sprouts during growth at $20{ }^{\circ} \mathrm{C}$. After 7 days in darkness, sprouts' length reached $2.61 \pm 0.16 \mathrm{~cm}$. When transferring samples to the photoperiod, the length of control samples grown in darkness increased up from $3.43 \pm 0.58 \mathrm{~cm}$ (after $3 \mathrm{dP}$ ) to $6.91 \pm 0.68 \mathrm{~cm}$ (after $10 \mathrm{dP}$ ) (hypocotyl from $2.51 \pm 0.22$ to $5.68 \pm 0.67 \mathrm{~cm}$, while root from $1.17 \pm 0.21$ to $1.23 \pm 0.34 \mathrm{~cm}$ ). The longest hypocotyls and sprouts were shown by samples grown under darkness conditions. In this way, carrot sprouts after 17 days at $20^{\circ} \mathrm{C}(7 \mathrm{dD}+10 \mathrm{dP})$ presented $64 \%, 67 \%$, and $68 \%$ shorter hypocotyls under $\mathrm{Fl}, \mathrm{B}+\mathrm{R}$, and $\mathrm{B}+\mathrm{R}+\mathrm{FR}$ lighting, than darkness treatment, respectively. There is not a clear trend in root growth due to the light exposure. Rate of sprout growth decreased by lighting (both $\mathrm{Fl}$ and LEDs). In fact, $\mathrm{Fl}$ lighting reduced the sprout growth by $37 \%$ compared to darkness, while $\mathrm{B}+\mathrm{R}$ and $\mathrm{B}+\mathrm{R}+\mathrm{FR}$ treatments reduced by $38 \%$ and $44 \%$ respectively, after $7 \mathrm{dD}+10 \mathrm{dP}$. Similarly, H/R ratio was also affected by light treatments, decreasing by $81 \%(\mathrm{Fl})$ and $78 \%(\mathrm{~B}+\mathrm{R}$ and $\mathrm{B}+\mathrm{R}+\mathrm{FR})$ after 17 days $(7 \mathrm{dD}+10 \mathrm{dP})$ concerning samples grown in darkness. After germination, carrot sprouts increased 4.5 -fold $(11.0 \pm 1.11 \mathrm{~g})$ their initial weight under darkness conditions, while under photoperiod, $\mathrm{Fl}, \mathrm{B}+\mathrm{R}$, and $\mathrm{B}+\mathrm{R}+\mathrm{FR}$ increased by $2.75-(7.50 \pm 1.25 \mathrm{~g}), 2.25-(6.5 \pm 1.56 \mathrm{~g})$, and 3-fold $(8.09 \pm 0.95 \mathrm{~g})$, without differences among them (data not shown).

Table 1. Morphological development of carrot sprouts grown at $20{ }^{\circ} \mathrm{C}$ during 7 days in darkness (dD) +10 days of a light/darkness photoperiod (dP) under several light treatments.

\begin{tabular}{|c|c|c|c|c|c|}
\hline Days at $20^{\circ} \mathrm{C}$ & Treatment & $\begin{array}{l}\text { Hypocotyl Length } \\
\text { (cm) }\end{array}$ & $\begin{array}{l}\text { Root Length } \\
\text { (cm) }\end{array}$ & $\begin{array}{l}\text { Sprout Length } \\
(\mathrm{cm})\end{array}$ & H/R Ratio \\
\hline \multicolumn{6}{|c|}{ Growing under darkness conditions } \\
\hline $3 \mathrm{dD}$ & Darkness & - & $0.24 \pm 0.03$ & $0.24 \pm 0.03$ & - \\
\hline $7 \mathrm{dD}$ & Darkness & $1.10 \pm 0.04$ & $1.52 \pm 0.18$ & $2.61 \pm 0.16$ & $0.83 \pm 0.08$ \\
\hline \multicolumn{6}{|c|}{ + days under a $16 \mathrm{~h}$ light $/ 8 \mathrm{~h}$ darkness photoperiod } \\
\hline \multirow{4}{*}{$7 \mathrm{dD}+3 \mathrm{dP}$} & Darkness & $2.51 \pm 0.22 \mathrm{Ab}$ & $1.17 \pm 0.21^{\mathrm{Bb}}$ & $3.43 \pm 0.58^{b}$ & $3.51 \pm 0.88^{\mathrm{A}}$ \\
\hline & $\mathrm{Fl}$ & $1.17 \pm 0.09^{\mathrm{B}}$ & $2.17 \pm 0.49^{\mathrm{A}}$ & $3.34 \pm 0.44$ & $0.64 \pm 0.22^{\mathrm{B}}$ \\
\hline & $\mathrm{B}+\mathrm{R}$ & $1.00 \pm 0.10^{\mathrm{B} \mathrm{b}}$ & $2.20 \pm 0.33^{\mathrm{A}}$ & $3.01 \pm 0.64$ & $0.50 \pm 0.08^{\mathrm{B} \mathrm{b}}$ \\
\hline & $\mathrm{B}+\mathrm{R}+\mathrm{FR}$ & $1.20 \pm 0.14^{\mathrm{B} \mathrm{b}}$ & $1.65 \pm 0.24 \mathrm{AB} \mathrm{b}$ & $2.85 \pm 0.30^{b}$ & $0.95 \pm 0.27^{\mathrm{B}}$ \\
\hline \multirow{4}{*}{$7 \mathrm{dD}+7 \mathrm{dP}$} & Darkness & $4.51 \pm 0.77 \mathrm{~A} \mathrm{a}$ & $2.41 \pm 0.32 \mathrm{AB}$ a & $6.92 \pm 1.04 \mathrm{~A} \mathrm{a}$ & $2.64 \pm 0.80^{\mathrm{A}}$ \\
\hline & $\mathrm{Fl}$ & $1.64 \pm 0.56^{\mathrm{B}}$ & $2.08 \pm 0.27^{\mathrm{B}}$ & $3.72 \pm 0.83^{\mathrm{B}}$ & $1.14 \pm 0.31^{\mathrm{B}}$ \\
\hline & $\mathrm{B}+\mathrm{R}$ & $1.22 \pm 0.10^{\mathrm{B} \mathrm{b}}$ & $2.10 \pm 0.25^{\mathrm{B}}$ & $3.32 \pm 0.28^{B}$ & $0.63 \pm 0.08^{\mathrm{BC} b}$ \\
\hline & $\mathrm{B}+\mathrm{R}+\mathrm{FR}$ & $1.21 \pm 0.07^{\mathrm{B} \mathrm{b}}$ & $3.09 \pm 0.43 \mathrm{~A} \mathrm{a}$ & $4.30 \pm 0.50 \mathrm{~B} \mathrm{a}$ & $0.43 \pm 0.00^{\mathrm{BC}}$ \\
\hline \multirow{4}{*}{$7 \mathrm{dD}+10 \mathrm{dP}$} & Darkness & $5.68 \pm 0.67 \mathrm{~A} \mathrm{a}$ & $1.23 \pm 0.34^{\mathrm{b}}$ & $6.91 \pm 0.68 \mathrm{~A} \mathrm{a}$ & $4.86 \pm 0.63^{\mathrm{A}}$ \\
\hline & $\mathrm{Fl}$ & $2.04 \pm 0.08^{\mathrm{B}}$ & $2.31 \pm 0.11$ & $4.35 \pm 0.18^{\mathrm{B}}$ & $0.89 \pm 0.03^{\mathrm{B}}$ \\
\hline & $\mathrm{B}+\mathrm{R}$ & $1.86 \pm 0.16^{\mathrm{B} \mathrm{a}}$ & $2.38 \pm 0.58$ & $4.24 \pm 0.74^{\mathrm{B}}$ & $1.07 \pm 0.14^{\mathrm{B} \mathrm{a}}$ \\
\hline & $\mathrm{B}+\mathrm{R}+\mathrm{FR}$ & $1.80 \pm 0.16^{\mathrm{B} \mathrm{b}}$ & $2.03 \pm 0.75^{a b}$ & $3.84 \pm 0.62^{\mathrm{B} \mathrm{ab}}$ & $1.06 \pm 0.44^{\mathrm{B}}$ \\
\hline
\end{tabular}

Fl: Fluorescence: B: Blue; R: Red; FR: Far-Red; H/R: Hypocotyl/Root. dD+dP: growth at $20^{\circ} \mathrm{C}$ during 7 days under darkness conditions +3 or 7 or 10 days under a $16 \mathrm{~h} / 8 \mathrm{~h}$ photoperiod. Different capital letters denote significant differences $(p<0.05)$ among different treatments for the same sampling time. Different lowercase letters denote significant differences $(p<0.05)$ among different sampling times for the same treatment. Absence of letters indicates that there are no significant differences $(p<0.05)$. 


\subsection{Total Phenolic Content}

Initially, the total phenolic content of the carrot seeds was $737.3 \pm 31.2 \mathrm{mg}$ chlorogenic acid $\mathrm{kg}^{-1} \mathrm{dw}$, while after 10 days $(7 \mathrm{dD}+3 \mathrm{dP})$, this value was increased more than 10 -fold up to $8494 \pm 299.3 \mathrm{mg}$ chlorogenic acid kg ${ }^{-1} \mathrm{dw}$, which was increased 2-fold on day 17 (Figure 4). In addition, on $7 \mathrm{dD}+3 \mathrm{dP}$ and $7 \mathrm{dD}+7 \mathrm{dP}$, carrot sprouts treated with $\mathrm{Fl}$ and LEDs lights $(\mathrm{B}+\mathrm{R}$ and $\mathrm{B}+\mathrm{R}+\mathrm{FR})$ did not present differences between them but increased almost twice the total phenolic content with regards to control treatment (darkness). Hence, seeds germinated under darkness conditions for $7 \mathrm{dD}+3 \mathrm{dP}$ and $7 \mathrm{dD}+7 \mathrm{dP}$ presented $50 \%$ lower concentration of phenolic compounds compared to those germinated under $\mathrm{Fl}$ and LEDs lighting during $3 \mathrm{dP}$ and $7 \mathrm{dP}$. Furthermore, it is remarkable that total phenolic content was kept stable during the 17 days $(7 \mathrm{dD}+10 \mathrm{dP})$ of germination only in the samples grown under $\mathrm{B}+\mathrm{R}$ LEDs, while $\mathrm{Fl}$ and $\mathrm{B}+\mathrm{R}+\mathrm{FR}$ treatments reduced the total phenolic content by $24 \%$ and $12 \%$ with regards to $7 \mathrm{dD}+7 \mathrm{dP}$ of sprouting, respectively.

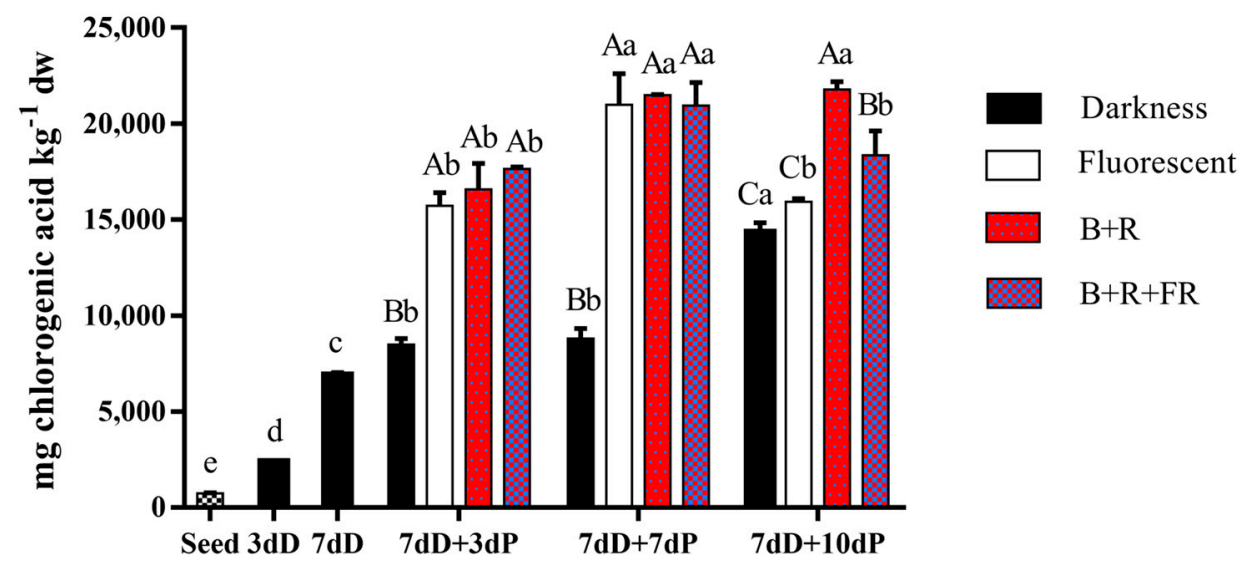

Figure 4. Total phenolic content of carrot sprouts grown at $20{ }^{\circ} \mathrm{C}$ during 7 days in darkness (dD) +3 or 7 or 10 days of a $16 \mathrm{~h} / 8 \mathrm{~h}$ photoperiod $(\mathrm{dP})$ under several light treatments. $\mathrm{B}+\mathrm{R}$ : Blue+Red; $\mathrm{B}+\mathrm{R}+\mathrm{FR}$ : Blue+Red+Far-Red LEDs. Different capital letters indicate significant differences among treatments at $p<0.05$ based on Tukey's test. Different lowercase letters indicate significant differences among time of analysis of the same treatment at $p<0.05$ based on Tukey's test.

\subsection{Total Antioxidant Capacity}

Table 2 shows the obtained results of TAC measured by the DPPH free radical scavenging method, FRAP, and ABTS+ radical cation assay. The TAC of carrot seeds measured by DPPH at the beginning of the study was $834.7 \pm 39.6 \mathrm{mg} \mathrm{TE} \mathrm{kg}^{-1}$, which increased to $7579.4 \pm 179.8 \mathrm{mg} \mathrm{TE} \mathrm{kg}^{-1}$ after 10 days $(7 \mathrm{dD}+3 \mathrm{dP})$ under darkness conditions. On the same sampling day, carrot sprouts treated by $\mathrm{Fl}$ or LED $(\mathrm{B}+\mathrm{R}$ or $\mathrm{B}+\mathrm{R}+\mathrm{FR})$ lighting increased the TAC by $44 \%, 50 \%$, and $55 \%$ with regards to the samples in darkness, respectively. Moreover, no differences were observed between the light treatments, except on $7 \mathrm{dD}+10 \mathrm{dP}$, when sprouts from the $\mathrm{Fl}$ treatment reported $39.4 \%$ less TAC than those grown under $\mathrm{B}+\mathrm{R}$ LEDs, which can also be related to the results obtained for TPC (Figure 4).

The initial TAC of carrot seeds by the FRAP method was $3230.7 \pm 194.0 \mathrm{mg} \mathrm{TE} \mathrm{kg}{ }^{-1}$, increasing twice under darkness conditions and 4-fold under $\mathrm{Fl}$ and LEDs lighting ( $\mathrm{B}+\mathrm{R}$ or $\mathrm{B}+\mathrm{R}+\mathrm{FR})$ after $7 \mathrm{dD}+3 \mathrm{dP}$. At this time, no differences were shown between light treatments. However, 7 days later, carrot sprouts under Fl lights presented $44 \%$ less TAC than B+R samples. In fact, this behavior is very similar to that previously described (DPPH and TPC); hence, changes on TPC can explain these variations on $7 \mathrm{dD}+10 \mathrm{dP}$. 
Table 2. Total antioxidant activity $\left(\mathrm{mg} \mathrm{TE} \mathrm{kg}^{-1} \mathrm{dw}\right)$ of carrot sprouts grown at $20{ }^{\circ} \mathrm{C}$ during 7 days in darkness (dD) +3 or 7 or 10 days of a $16 \mathrm{~h} / 8 \mathrm{~h}$ photoperiod $(\mathrm{dP})$ under several light treatments.

\begin{tabular}{|c|c|c|c|c|c|c|}
\hline \multirow[b]{2}{*}{ Treatment } & \multirow[b]{2}{*}{ Seed } & \multirow[b]{2}{*}{$3 \mathrm{dD}$} & \multicolumn{4}{|c|}{ Days at $20^{\circ} \mathrm{C}$} \\
\hline & & & $7 \mathrm{dD}$ & $7 \mathrm{dD}+3 \mathrm{dP}$ & $7 \mathrm{dD}+7 \mathrm{dP}$ & $7 \mathrm{dD}+10 \mathrm{dP}$ \\
\hline $\begin{array}{c}\text { Darkness } \\
\text { Fl } \\
\text { B+R } \\
B+R+F R\end{array}$ & $834.7 \pm 39.6^{d}$ & $1508.6 \pm 81.0^{c}$ & $4351.8 \pm 366.6^{b}$ & $\begin{array}{c}7579.4 \pm 179.8^{\mathrm{B} \mathrm{a}} \\
10916.7 \pm 58.9^{\mathrm{A} \mathrm{a}} \\
11352.7 \pm 919.3^{\mathrm{A} \mathrm{b}} \\
11737.9 \pm 817.4^{\mathrm{A} \mathrm{a}}\end{array}$ & $\begin{array}{c}4324.5 \pm 25.6^{\mathrm{B} \mathrm{b}} \\
11921.9 \pm 1278.3^{\mathrm{A} \mathrm{a}} \\
13019.6 \pm 1065.8^{\mathrm{A} \mathrm{ab}} \\
11390.6 \pm 1338.7^{\mathrm{A} \mathrm{a}}\end{array}$ & $\begin{array}{c}8403.3 \pm 888.4^{\mathrm{Ca}} \\
11803.7 \pm 234.5^{\mathrm{B} \mathrm{a}} \\
13877.1 \pm 371.8^{\mathrm{A} \mathrm{a}} \\
12920.9 \pm 563.2^{\mathrm{AB} \mathrm{a}}\end{array}$ \\
\hline \multicolumn{7}{|c|}{ FRAP } \\
\hline $\begin{array}{c}\text { Darkness } \\
\text { Fl } \\
\mathrm{B}+\mathrm{R} \\
\mathrm{B}+\mathrm{R}+\mathrm{FR} \\
\end{array}$ & $3230.7 \pm 194.0^{d}$ & $2720.3 \pm 261.2^{d}$ & $5106.3 \pm 377.6^{c}$ & $\begin{array}{c}7292.7 \pm 357.7^{\mathrm{Cb}} \\
11425.9 \pm 451.6^{\mathrm{B} \mathrm{b}} \\
12035.0 \pm 561.4^{\mathrm{AB} \mathrm{b}} \\
12983.3 \pm 449.5^{\mathrm{Ab}}\end{array}$ & $\begin{array}{c}7149.8 \pm 449.5^{\mathrm{Cb}} \\
13421.7 \pm 705.6^{\mathrm{A} \mathrm{a}} \\
11005.4 \pm 1267.0^{\mathrm{B} \mathrm{b}} \\
12050.6 \pm 841.9^{\mathrm{AB} \mathrm{b}}\end{array}$ & $\begin{array}{l}8653.2 \pm 247.6^{\mathrm{Ca}} \\
10182.2 \pm 742.4^{\mathrm{Cb}} \\
18148.6 \pm 563.4^{\mathrm{A} \mathrm{a}} \\
15121.1 \pm 683.9^{\mathrm{B} \mathrm{a}}\end{array}$ \\
\hline \multicolumn{7}{|c|}{ ABTS } \\
\hline $\begin{array}{c}\text { Darkness } \\
\text { Fl } \\
\mathrm{B}+\mathrm{R} \\
\mathrm{B}+\mathrm{R}+\mathrm{FR}\end{array}$ & $1944.8 \pm 144.4^{\mathrm{d}}$ & $1722.3 \pm 158.3^{d}$ & $5522 \pm 395.4^{c}$ & $\begin{array}{c}7944.5 \pm 636.3^{\mathrm{Bb}} \\
13378.2 \pm 982.2^{\mathrm{Ab}} \\
13853.0 \pm 796.1^{\mathrm{A} \mathrm{a}} \\
13633.0 \pm 812.0^{\mathrm{A} \mathrm{a}}\end{array}$ & $\begin{array}{c}6862.6 \pm 123.2^{\mathrm{B} \mathrm{b}} \\
16069.7 \pm 1257.9^{\mathrm{A} \mathrm{a}} \\
14766.9 \pm 890.4^{\mathrm{A} \mathrm{a}} \\
14775.8 \pm 1085.1^{\mathrm{A} \mathrm{a}}\end{array}$ & $\begin{array}{l}11400.4 \pm 1152.5^{\mathrm{Ca}} \\
13825.3 \pm 669.9^{\mathrm{B} \mathrm{ab}} \\
15253.6 \pm 295.4^{\mathrm{A} \mathrm{a}} \\
15529.4 \pm 518.8^{\mathrm{A} \mathrm{a}}\end{array}$ \\
\hline
\end{tabular}

TE: Trolox Equivalents. Mean \pm standard deviation (SD). Fl: Fluorescence: B: Blue; R: Red; FR: Far-Red. dD+dP: days under darkness conditions + days under a $16 \mathrm{~h} / 8 \mathrm{~h}$ photoperiod. Different capital letters denote significant differences $(p<0.05)$ among different treatments for the same sampling time. Different lowercase letters denote significant differences $(p<0.05)$ among different sampling times for the same treatment. Absence of letters indicates that there are no significant differences $(p<0.05)$.

The TAC of carrot seeds measured by the ABTS assay was $1944.8 \pm 144.4 \mathrm{mg} \mathrm{TE} \mathrm{kg}^{-1}$. This value was increased four times under darkness conditions and seven times under $\mathrm{Fl}$ and LED lighting after $7 \mathrm{dD}+3 \mathrm{dP}$. In this case, LED lighting (both $\mathrm{B}+\mathrm{R}$ and $\mathrm{B}+\mathrm{R}+\mathrm{FR}$ ) kept stable values until the end of the study, while carrot sprouts under Fl lighting decreased the TAC by $25 \%$ and $27 \%$ respectively, compared to LED lighting on $7 \mathrm{dD}+10 \mathrm{dP}$.

In Figure 5, TAC index (Figure 5A) and total scavenging activity index (Figure 5B) are shown. Firstly, TAC (Figure 5A) of carrot seeds measured by DPPH, FRAP, and ABTS was $2003.4 \pm 79.2 \mathrm{mg} \mathrm{TE} \mathrm{kg}^{-1} \mathrm{dw}$, which increased after sprouting twice and almost four times $(7 \mathrm{dD}+10 \mathrm{dP})$ under darkness conditions. Furthermore, light treatments increased the total TAC index by $62 \%(\mathrm{Fl}), 77 \%(\mathrm{~B}+\mathrm{R})$, and $73 \%(\mathrm{~B}+\mathrm{R}+\mathrm{FR})$ with regards to the control sample (darkness). In addition, $\mathrm{B}+\mathrm{R}$ kept the TAC of carrot sprouts stable during the study, showing the highest values, without differences with $\mathrm{B}+\mathrm{R}+\mathrm{FR}$ treatment. Otherwise, $\mathrm{Fl}$ lighting showed a reduction of $13.5 \%$ among $7 \mathrm{dD}+7 \mathrm{dP}$ and $7 \mathrm{dD}+10 \mathrm{dP}$ of sprouting. Therefore, combination of LED lighting reported the best results of TAC.

The scavenging activity (Figure 5B) of the studied phenolic compounds leads to the ability to quench free radicals, blocking its reactivity and inhibiting the generation of new radicals able to affect the cells (both vegetal and animal, in this case those of consumers). In this way, the scavenging activity of carrot seeds studied was $10.9 \% \pm 0.6 \%$, which was increased after sprouting in a similar manner, as previously described (Figure 5A). Hence, a general increase is shown under $\mathrm{Fl}$ and LED lighting. However, only the combinations of LEDs $(\mathrm{B}+\mathrm{R}$ or $\mathrm{B}+\mathrm{R}+\mathrm{FR})$ were able to maintain the scavenging capacity $(>60 \%)$ on day $7 \mathrm{dD}+10 \mathrm{dP}$ of the study compared to $\mathrm{Fl}$, which reported a decrease of $\sim 10 \%$, while darkness showed $\sim 29 \%$ less scavenging activity than carrot sprouts under LED lighting on the same day.

High correlations $(\mathrm{R} 2>0.900)$ between TAC (measured by DPPH $\left(\mathrm{R}^{2}=0.9713\right)$, FRAP $\left(R^{2}=0.9291\right)$, and ABTS $\left.\left(R^{2}=0.9836\right)\right)$ and TPC (measured by Folin-Ciocalteu method), were obtained for the studied carrot sprouts. 
A

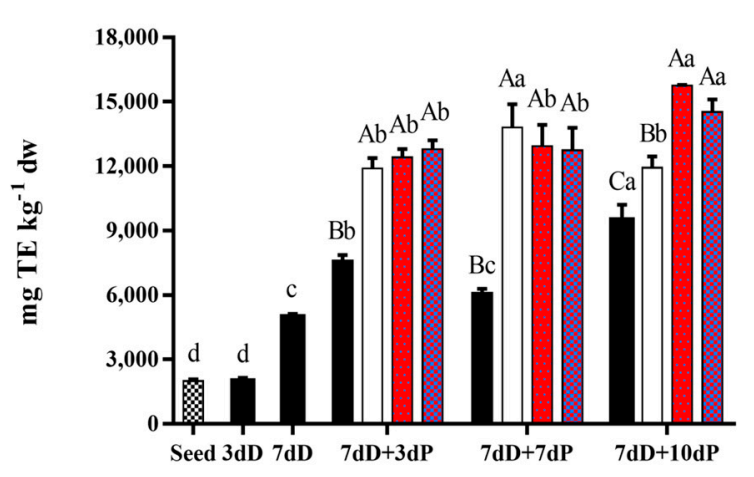

B

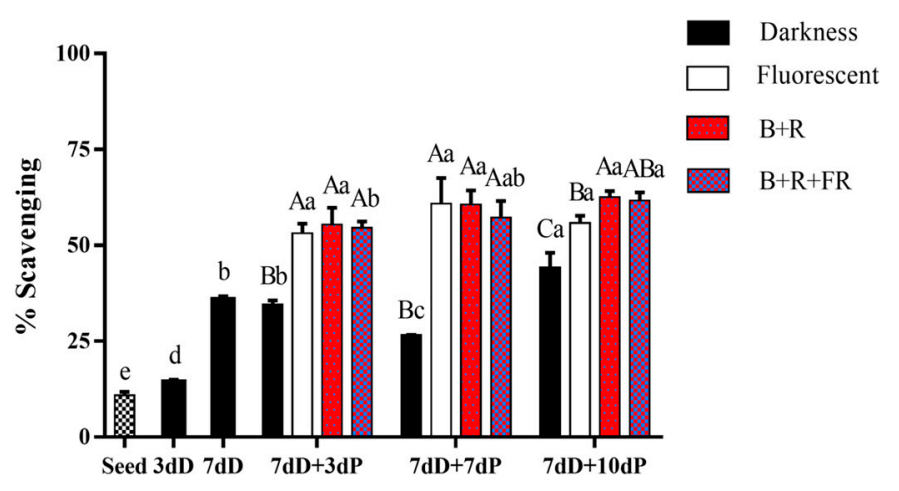

Figure 5. Total antioxidant capacity index (A) and total scavenging activity Index (B) of carrot sprouts grown at $20{ }^{\circ} \mathrm{C}$ during 7 days in darkness $(\mathrm{dD})+3$ or 7 or 10 days of a $16 \mathrm{~h} / 8 \mathrm{~h}$ photoperiod $(\mathrm{dP})$ under several light treatments. $\mathrm{B}+\mathrm{R}$ : Blue+Red; B+R+FR: Blue+Red+Far-Red LEDs. Different capital letters indicate significant differences among treatments at $p<0.05$ based on Tukey's test. Different lowercase letters indicate significant differences among time of analysis of the same treatment at $p<0.05$ based on Tukey's test.

\subsection{Individual Phenolic Content}

Seven phenolic acids (neochlorogenic, chlorogenic, caffeic, p-coumaric, ferulic, hydroxycinnamic acid, and 1,2-disinapoyl-1'-ferulolylgentiobiose) and one flavonoid (rutin) were identified (Figure 2) in carrot sprouts grown during 17 days at $20^{\circ} \mathrm{C}$ under different light treatments (Table 3). Values found for total individual phenolic content differ from those of total phenolic content (Figure 4). Although the same trend was observed, this variation can be explained by the method specificity $[22,23]$, the equipment, and the fact that peaks with very reduced area were not identified.

Actually, carrot sprouts under darkness conditions reported at least $35 \%$ less phenolic content than all the studied light treatments, even though the p-coumaric acid and the hydroxycinnamic acid content showed values $20 \%$ lower. For that, it can be accepted that applied doses of lighting (168-197 $\left.\mu \mathrm{mol} \mathrm{m}^{-2} \mathrm{~s}^{-1}\right)$, either Fl or LED, enhanced the individual phenolic content by $45-65 \%$ in carrot sprouts.

On average, $\mathrm{B}+\mathrm{R}+\mathrm{FR}$ treatment reported the highest phenolic content followed by $\mathrm{B}+\mathrm{R}$ and Fl. In fact, after collecting carrot sprouts, on 3rd (7 dD+3 dP), 7th (7 dD+7 dP), or 10th days $(7 \mathrm{dD}+10 \mathrm{dP})$ under $\mathrm{B}+\mathrm{R}+\mathrm{FR}$ photoperiod treatment, the total phenolic content (obtained by adding all peaks) increased by $64 \%$ regarding darkness treatment. Besides that, it seems that the incorporation of FR LED lighting intensified the biosynthesis of individual phenolic content by $11 \%$ compared to B+R. Moreover, $\mathrm{Fl}$ treatment showed $32 \%$ less phenolic content than $\mathrm{B}+\mathrm{R}+\mathrm{FR}$, which can also be related to Folin-Ciocalteau results (Figure 4).

Specifically, the main phenolic compounds identified (neochlorogenic, chlorogenic, caffeic acid, rutin, and 1,2-disinapoyl-1'-ferulolylgentiobiose) were increased $(\geq 10 \%)$ by the incorporation of FR to the LED treatment, while some phenolic acids (p-coumaric, ferulic, and hydroxycinnamic acid) did not report significant differences among $\mathrm{B}+\mathrm{R}$ and $\mathrm{B}+\mathrm{R}+\mathrm{FR}$ treatments. Therefore, it is possible to conclude that FR LED lighting during sprouting is able to enhance the biosynthesis of some phenolic compounds by $10 \%$ in carrot sprouts. 


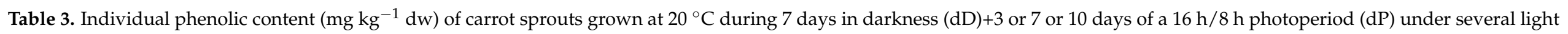
treatments.

\begin{tabular}{|c|c|c|c|c|c|c|c|c|c|c|}
\hline Treatment & $\begin{array}{c}\text { Day of } \\
\text { Analysis }\end{array}$ & $\begin{array}{c}\text { Neochlorogenic } \\
\text { Acid }\end{array}$ & Chlorogenic Acid & Caffeic Acid & $p$-Coumaric Acid & Ferulic Acid & $\begin{array}{c}\text { Hydroxycinnamic } \\
\text { Acid }\end{array}$ & Rutin & $\begin{array}{l}\text { 1,2-Disinapoyl-1'- } \\
\text { Ferulolylgentiobiose }\end{array}$ & $\begin{array}{c}\text { Total Individual } \\
\text { Phenols }\end{array}$ \\
\hline Seed & $0 \mathrm{dD}$ & $131.9 \pm 16.6^{\mathrm{ab}}$ & $7.0 \pm 0.17^{c}$ & $0.2 \pm 0.02^{c}$ & $207.8 \pm 17.8^{\mathrm{c}}$ & $0.2 \pm 0.0^{c}$ & $0.5 \pm 0.0^{\mathrm{c}}$ & $6.2 \pm 0.5^{c}$ & $0.4 \pm 0.0^{\mathrm{d}}$ & $354.1 \pm 33.4^{\mathrm{e}}$ \\
\hline \multicolumn{11}{|c|}{ Growing under darkness conditions } \\
\hline & $3 \mathrm{dD}$ & $99.0 \pm 11.7^{\mathrm{bc}}$ & $8.9 \pm 4.6^{c}$ & $5.4 \pm 2.4^{\mathrm{c}}$ & $129.5 \pm 11.0^{\mathrm{d}}$ & $12.3 \pm 2.8^{\mathrm{c}}$ & $1.1 \pm 0.0^{\mathrm{c}}$ & $7.7 \pm 0.7^{c}$ & $4.1 \pm 0.7^{\mathrm{d}}$ & $268.1 \pm 34.8^{\mathrm{e}}$ \\
\hline & $7 \mathrm{dD}$ & $127.5 \pm 8.6^{\mathrm{ab}}$ & $420.5 \pm 20.9^{b}$ & $42.7 \pm 8.6^{b}$ & $246.5 \pm 23.3^{b c}$ & $1396.8 \pm 45.1^{\mathrm{b}}$ & $37.5 \pm 3.6^{c}$ & $141.0 \pm 17.3^{\mathrm{b}}$ & $20.8 \pm 6.4^{c}$ & $2433.3 \pm 110.6^{d}$ \\
\hline \multicolumn{11}{|c|}{ + days under a 16h light $/ 8 \mathrm{~h}$ darkness photoperiod } \\
\hline \multirow{3}{*}{ Darkness } & $7 \mathrm{dD}+3 \mathrm{dP}$ & $68.7 \pm 8.2^{\mathrm{Cc}}$ & $506.1 \pm 52.6^{\mathrm{Db}}$ & $77.7 \pm 4.7^{\mathrm{B} \mathrm{a}}$ & $282.9 \pm 29.1^{B b}$ & $1841.7 \pm 111.4^{\mathrm{Da}}$ & $85.9 \pm 22.7^{\mathrm{Bb}}$ & $158.3 \pm 0.8^{\mathrm{Cab}}$ & $53.6 \pm 7.9 \mathrm{Cb}$ & $3074.9 \pm 164.4^{\mathrm{Dc}}$ \\
\hline & $7 \mathrm{dD}+7 \mathrm{dP}$ & $129.2 \pm 1.9 \mathrm{Cab}$ & $444.5 \pm 31.5 \mathrm{Cb}$ & $77.7 \pm 20.7$ В а & $400.7 \pm 40.1$ В а & $1972.2 \pm 142.4 \mathrm{Ca}$ & $358.3 \pm 18.0^{\mathrm{Ca}}$ & $126.2 \pm 18.4 \mathrm{Cb}$ & $38.7 \pm 6.8^{\mathrm{Cb}}$ & $3547.5 \pm 269.3^{\mathrm{Cb}}$ \\
\hline & $7 \mathrm{dD}+10 \mathrm{dP}$ & $134.9 \pm 1.5^{\mathrm{Ca}}$ & $943.2 \pm 52.0^{\mathrm{Ca}}$ & $102.7 \pm 13.9^{\text {В а }}$ & $418.5 \pm 7.1^{\mathrm{B} \mathrm{a}}$ & $1852.5 \pm 135.4^{\mathrm{Ca}}$ & $366.1 \pm 20.3^{\mathrm{A} \mathrm{a}}$ & $182.5 \pm 12.3^{\text {В а }}$ & $81.8 \pm 7.0^{\mathrm{Ca}}$ & $4082.2 \pm 151.5^{\mathrm{Ca}}$ \\
\hline \multirow{3}{*}{ Fl } & $7 \mathrm{dD}+3 \mathrm{dP}$ & $211.6 \pm 1.4^{\mathrm{A} \mathrm{a}}$ & $1800.7 \pm 135.3^{\mathrm{Ca}}$ & $212.5 \pm 2.9 \mathrm{~A} \mathrm{a}$ & $470.7 \pm 41.3^{\mathrm{A}}$ & $2654.9 \pm 53.5^{\mathrm{Cb}}$ & $149.7 \pm 15.2^{\mathrm{Bb}}$ & $909.2 \pm 9.3^{\mathrm{B} \mathrm{a}}$ & $158.1 \pm 14.2^{\mathrm{B} \mathrm{b}}$ & $6567.5 \pm 220.8^{\mathrm{Cb}}$ \\
\hline & $7 \mathrm{dD}+7 \mathrm{dP}$ & $194.4 \pm 5.9 \mathrm{Ab}$ & $1886.7 \pm 91.3^{\text {В а }}$ & $191.7 \pm 19.1 \mathrm{~A} \mathrm{a}$ & $526.2 \pm 36.6^{\mathrm{AB}}$ & $3226.6 \pm 262.9$ В а & $460.1 \pm 46.7^{\text {В а }}$ & $804.9 \pm 51.9 \mathrm{Aa}$ & $194.2 \pm 13.7$ В а & $7484.8 \pm 303.8$ В а \\
\hline & $7 \mathrm{dD}+10 \mathrm{dP}$ & $168.1 \pm 4.1 \mathrm{Bc}$ & $1437.4 \pm 131.0^{B ~ b}$ & $110.8 \pm 3.7^{\mathrm{B} \mathrm{b}}$ & $424.0 \pm 45.2^{\mathrm{B}}$ & $2816.6 \pm 172.2^{\mathrm{B} \text { ab }}$ & $398.2 \pm 28.0^{\mathrm{A} \mathrm{a}}$ & $506.5 \pm 55.5 \mathrm{~A} \mathrm{~b}$ & $157.6 \pm 11.8^{\mathrm{B} \mathrm{b}}$ & $6019.3 \pm 384.5^{\mathrm{B} \mathrm{b}}$ \\
\hline \multirow{3}{*}{$\mathbf{B}+\mathbf{R}$} & $7 \mathrm{dD}+3 \mathrm{dP}$ & $150.7 \pm 15.8^{\text {B b }}$ & $2202.3 \pm 31.3^{\text {B ab }}$ & $197.0 \pm 15.4^{\mathrm{A} \mathrm{a}}$ & $524.6 \pm 30.1^{\mathrm{A}}$ & $3968.8 \pm 144.1^{\mathrm{B}}$ & $279.3 \pm 35.8^{\mathrm{Ab}}$ & $949.3 \pm 63.7^{\text {В а }}$ & $159.2 \pm 6.5^{\mathrm{Bb}}$ & $8431.1 \pm 171.1^{\text {B }}$ \\
\hline & $7 \mathrm{dD}+7 \mathrm{dP}$ & $170.0 \pm 16.2^{\mathrm{Bb}}$ & $1985.1 \pm 128.0^{\mathrm{B} \mathrm{b}}$ & $132.1 \pm 11.5 \mathrm{AB} \mathrm{b}$ & $613.0 \pm 54.7^{\mathrm{A}}$ & $4423.9 \pm 327.4^{\mathrm{A}}$ & $615.0 \pm 24.0^{\mathrm{A} \mathrm{a}}$ & $550.2 \pm 14.8^{\mathrm{B} \mathrm{b}}$ & $231.9 \pm 23.2 \mathrm{AB} \mathrm{a}$ & $8721.1 \pm 567.7 \mathrm{AB}$ \\
\hline & $7 \mathrm{dD}+10 \mathrm{dP}$ & $217.6 \pm 17.4 \mathrm{~A} \mathrm{a}$ & $2489.8 \pm 202.5^{\mathrm{A} \mathrm{a}}$ & $206.3 \pm 5.8^{\mathrm{A} \mathrm{a}}$ & $602.6 \pm 18.4^{\mathrm{A}}$ & $4205.2 \pm 403.3^{\mathrm{A}}$ & $569.3 \pm 16.9^{\mathrm{A} \mathrm{a}}$ & $601.4 \pm 58.6^{\mathrm{Ab}}$ & $262.0 \pm 15.1 \mathrm{~A} \mathrm{a}$ & $9154.2 \pm 835.5^{\mathrm{A}}$ \\
\hline \multirow{3}{*}{$\mathrm{B}+\mathrm{R}+\mathrm{FR}$} & $7 \mathrm{dD}+3 \mathrm{dP}$ & $194.9 \pm 22.5^{\mathrm{A}}$ & $2967.2 \pm 126.1^{\mathrm{A} \mathrm{a}}$ & $227.9 \pm 17.3^{\mathrm{Aa}}$ & $547.3 \pm 69.6^{\mathrm{A}}$ & $4677.7 \pm 281.2^{\mathrm{A}}$ & $322.4 \pm 25.9 \mathrm{Ab}$ & $1213.1 \pm 69.5^{\mathrm{A} \mathrm{a}}$ & $337.2 \pm 29.2^{\mathrm{A} a}$ & $10487.7 \pm 390.7^{\mathrm{A}}$ \\
\hline & $7 \mathrm{dD}+7 \mathrm{dP}$ & $206.8 \pm 1.8^{\mathrm{A}}$ & $2601.3 \pm 155.6^{\mathrm{Ab}}$ & $162.6 \pm 9.0 \mathrm{~A} \mathrm{~b}$ & $618.7 \pm 71.9^{\mathrm{A}}$ & $4385.5 \pm 440.1^{\mathrm{A}}$ & $537.3 \pm 9.4 \mathrm{AB} \mathrm{a}$ & $616.5 \pm 12.7$ В b & $272.9 \pm 18.1 \mathrm{~A} \mathrm{~b}$ & $9401.7 \pm 648.1^{\mathrm{A}}$ \\
\hline & $7 \mathrm{dD}+10 \mathrm{dP}$ & $201.2 \pm 12.5^{\mathrm{A}}$ & $2492.4 \pm 89.3^{\mathrm{Ab}}$ & $220.4 \pm 8.6^{\mathrm{A} \mathrm{a}}$ & $657.9 \pm 38.0^{\mathrm{A}}$ & $4631.0 \pm 164.4^{\mathrm{A}}$ & $512.0 \pm 10.7^{\mathrm{A} \mathrm{a}}$ & $632.9 \pm 23.9 \mathrm{Ab}$ & $296.7 \pm 20.7^{\mathrm{A} \mathrm{ab}}$ & $9644.4 \pm 114.2^{\mathrm{A}}$ \\
\hline
\end{tabular}

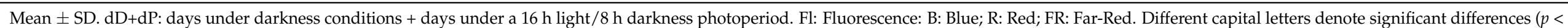

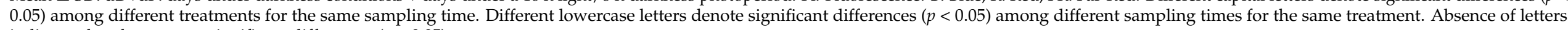
indicates that there are no significant differences $(p<0.05)$. 
$\mathrm{B}+\mathrm{R}$ and $\mathrm{B}+\mathrm{R}+\mathrm{FR}$ have shown the highest concentrations of phenolic compounds. Moreover, 3 days under LED lighting is enough to increase the concentration of phenolic compounds. Indeed, no great differences can be observed among different collecting days under these conditions. However, darkness treatment showed a slight rise through sprouting period (from $7 \mathrm{dD}+3 \mathrm{dP}$ to $7 \mathrm{dD}+10 \mathrm{dP}$ ) without reaching the concentration of bioactive compounds shown by $\mathrm{Fl}, \mathrm{B}+\mathrm{R}$, or/and $\mathrm{B}+\mathrm{R}+\mathrm{FR}$. For this reason, and thanks to the application of light during growth, the optimum time for harvesting carrot sprouts has been reduced by 7 days (to $7 \mathrm{dD}+3 \mathrm{dP}$ ), in terms of phenolic compound content, antioxidant capacity, and morphological characteristics, which would mean effective economic savings in industries dedicated to the cultivation of sprouts.

\subsection{Carotenoids}

The carotenoids found in carrot sprouts grown up to $7 \mathrm{dD}+10 \mathrm{dP}$ under different lighting treatments were all-trans neoxanthin, lutein, $\beta$-carotene, and their cis-isomers (Table 4). All the identified carotenoids are shown in Figure 3. The total carotenoid content in carrot seeds was $7.3 \pm 0.2 \mathrm{mg} \mathrm{kg}^{-1}$, from which all-trans lutein and $\beta$-carotene cisisomers were the main carotenoids found $(60 \%)$. The carotenoid synthesis increased when sprouts were moved from darkness to light photoperiod. After a 3-day light stimulus (Fl and both $\mathrm{B}+\mathrm{R}$ and $\mathrm{B}+\mathrm{R}+\mathrm{FR}$ LED treatments), an increase in the total carotenoid content by $237 \%, 290 \%$, and $153 \%$ was respectively found on $7 \mathrm{dD}+3 \mathrm{dP}$, which was higher for $\mathrm{B}+\mathrm{R}$ LED related to the other treatments. However, no significant differences were found between $\mathrm{Fl}$ and $\mathrm{B}+\mathrm{R}$ LED treatments after $7 \mathrm{dD}+10 \mathrm{dP}$. A higher proportion of red and blue LED light $(B+R)$ increased the all-trans $\beta$-carotene and its cis-isomers in carrot sprouts after $7 \mathrm{dD}+10 \mathrm{dP}$ of germination compared to $\mathrm{B}+\mathrm{R}+\mathrm{FR}$. While the FR spectra supplementation $(B+R+F R)$ did not show significant differences over the rest of the individual carotenoids compared to $\mathrm{B}+\mathrm{R}$.

In addition, the yellowish pigmentation of the roots and the green coloring of the first leaves of carrot sprouts under light conditions show an increase in carotene and lutein content, respectively. The sprouts under dark conditions had colorless and thinner roots, as well as a white hypocotyl and yellowish leaves. These effects of B, R, and FR light on carrot sprouts have not been previously published in the bibliography. 


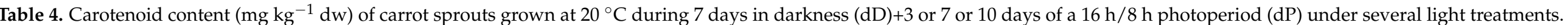

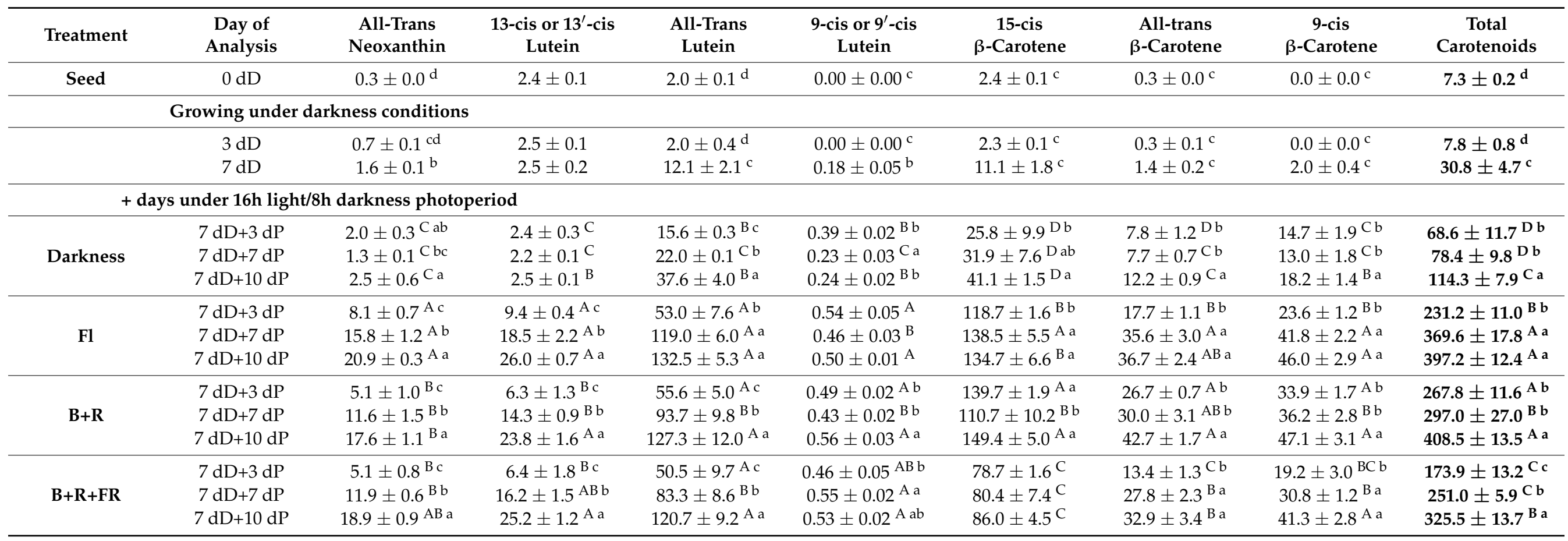

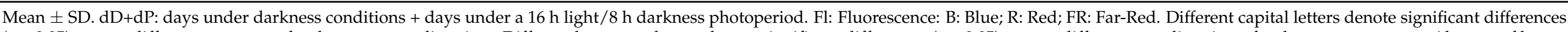

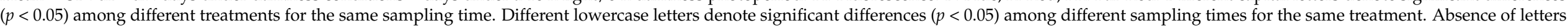
indicates that there are no significant differences $(p<0.05)$. 


\section{Discussion}

Darkness conditions favored a rapid growth of the hypocotyl in order to reach the soil (etiolation), depleting seed reserves [6]. Phytochromes and cryptochromes are responsible for promoting the appearance of cotyledons in order to start the photosynthetic cycle [6]. These results can be explained by different behaviors of LED application during plant growing, which several authors have already studied. For instance, red and far-red LED lighting showed a decrease in the elongation of the hypocotyl, acting through the phytochromes phyB and phyA, respectively [24,25]. Furthermore, blue light strongly inhibits stem elongation under high light rates [26]. This inhibition is mainly caused by cryptochromes, and it is maintained as long as blue light is present during the plant growth [27]. In this sense, Ohtake et al. [10] and Kuno et al. [28] reported that alternation of preharvest blue and red LED lighting in lettuce showed better results than combination of those lights.

Besides, similar values shown by carrot sprouts under a Fl photoperiod for 10 days can also be justified by the spectral composition of this light (Figure 1), with no significant differences. In fact, the high content of blue, green, and red in the Fl light spectrum is shown in Figure 1, which may also be related to that mentioned above [24-27].

There are some previous studies which reported that light has the ability to increase the phenolic compounds content in sprouts. For instance, Park et al. [29] showed an increase of $10-30 \%$ phenolic compounds after growing canola sprouts for 14 days under a $16 \mathrm{~h}$ blue photoperiod (flux rate of $50 \mu \mathrm{mol} \mathrm{s}^{-1} \mathrm{~m}^{-2}$ ) at $25^{\circ} \mathrm{C}$ compared to white and red treatments. Also, Kwack et al. [11] showed an increase of the total phenolic content after 3 days of blue, red, and green lighting compared to control treatment (darkness) before harvesting (on the 5th day) in alfalfa, broccoli, clover, kohlrabi, radish, and red radish sprouts. Similarly, Liu et al. [30] has also shown a $25 \%$ increase of the total phenolic content in pea sprouts grown under blue, red, and white lighting $\left(2 \mathrm{mg} \mathrm{GAE} \mathrm{g}^{-1} \mathrm{dw}\right)$ compared to darkness and yellow lighting $\left(1.5 \mathrm{mg} \mathrm{GAE} \mathrm{g}^{-1} \mathrm{dw}\right)$. Hence, the increase of the total phenolic content of carrot sprouts exposed to alternating blue and red LED lighting and fluorescent lamps can be considered adequate for sprouts' quality.

Previous studies found that the combination of blue and red lights, both simultaneously [31] and separately [32], increased the total phenolic content by improving photosynthesis, as well as the malonyl-CoA production, which is associated with the synthesis of phenolic compounds. In this sense, our results demonstrate for the first time that the application of blue and red LED lighting in separate phases of the light cycle during carrot sprouting improved the total phenolic content.

Described results of individual phenolic content can be justified by the normal behavior of young plants exposed to lighting from different wavelengths. As previously described, B and R lights selectively activate different photoreceptors related to photosynthesis, plant development, and synthesis of bioactive compounds like cryptochromes [7], phototropins [6], Zeitlupe family proteins [8], and phytochromes [9]. According to Hossen [33], rutin biosynthesis in buckwheat sprouts has also been influenced by the different combinations of LEDs and lighting cycles $(B+R+F R$ and $B+R+G)$ simultaneously applied. Results obtained from that study indicated that $12 \mathrm{~h}$ photoperiod and $\mathrm{B}+\mathrm{R}+\mathrm{FR}$ and $\mathrm{B}+\mathrm{R}+\mathrm{G}$ simultaneous combination of LEDs produced significantly higher amounts of rutin in buckwheat sprouts. Also, our last findings in minimally processed broccoli sprouts showed an increase of phenolic content (individual and total phenolic content) and TAC after the application of postharvest FR LED illumination during 15 days at $5{ }^{\circ} \mathrm{C}$ compared to $\mathrm{Fl}, \mathrm{B}$, and $\mathrm{R}$ lights, individually applied [20].

In addition, other authors have also reported that supplemental FR lighting to $B+R$ LEDs during growth of Crepidiastrum denticulatum improved the concentration of chlorogenic, caffeic, and chicoric acid phenolic compounds 2-fold compared to the B+R illumination [34], simultaneously applied, which can explain the obtained results in the present study.

Rodríguez-Concepción and Stange [35] reported a higher accumulation of $\beta$-carotene after root thickening (2-month carrot) in darkness. However, the chloroplasts are differ- 
entiated when the carrot roots are illuminated, and the carotenoid profile was like that of leaves with an increase of lutein content. In fact, Frede et al. [36] reported a higher ratio of lutein and $\beta$-carotene in pak choi sprouts under different light qualities compared to dark-grown sprouts. Roots under lighting conditions of 4-week carrot sprouts showed similar total carotenoid content to that of our 17 -day sprouts under photoperiod $(16 / 8 \mathrm{~h})$. In this way, similarly to our results, the total carotenoids content of roots under darkness conditions was lower than under light conditions [35].

Carotenoids play a fundamental role in protecting the photosynthetic mechanism of plants against photooxidative damage caused by excessive light energy [35]. The increase in carotenoids after the change of sprout conditions from darkness to light shows the beginning of the de-etiolation process [36]. In addition, carotene cis-isomers concentration increased with respect to trans-isomers amount during the germination in light conditions. This behavior is due to the photoisomerization of trans-isomers under light [21].

The effect of LED light on carotenoid content depends on the species, varieties, or irradiance levels (PPF). Brazaityte et al. [37] reported that supplemental blue, red, and green LED light increase the content of $\alpha$-carotene and $\beta$-carotene of Brassicaceae microgreens. In general terms, red light promotes photosynthesis and improves vegetative growth by increasing the chlorophyll content, and blue light is absorbed by carotenoid pigments, favoring the opening of the stomas [9]. In this sense, also, Huang et al. [32] have recently shown that a $4 \mathrm{~h}$ interval of supplemental red and blue lights (16 h in total: $\left.1250 \mathrm{~kJ} \mathrm{~m}^{-2}\right)$, alternatively applied, improves the accumulation of phenolic compounds and carotenoids in green-leaf and red-leaf pak choi. However, the ratio of red and blue light must be optimized for each species [38].

\section{Conclusions}

We have reported an initial overview of how carrot sprouts' germination and growth are affected by several alternating LED light treatments. Darkness conditions improved morphological growth regarding $\mathrm{Fl}$ and LED lighting. However, $\mathrm{B}+\mathrm{R}$ and $\mathrm{B}+\mathrm{R}+\mathrm{FR}$ treatments stimulated the phenolic and carotenoid synthesis (total and individual), subsequently increasing the total antioxidant capacity. Indeed, the phenolic content was increased by $45 \%$ and $65 \%$ after LED lighting $(\mathrm{B}+\mathrm{R}$ and $\mathrm{B}+\mathrm{R}+\mathrm{FR})$, while the carotenoids content increased by $279 \%$ and $220 \%$ respectively, during the 10 days of the photoperiod assayed, compared to darkness treatment. Besides that, $\mathrm{B}+\mathrm{R}$ and $\mathrm{B}+\mathrm{R}+\mathrm{FR}$ treatments were able to maintain the increased total antioxidant capacity and the biosynthesis of bioactive compounds from $7 \mathrm{dD}+3 \mathrm{dP}$ to $7 \mathrm{dD}+10 \mathrm{dP}$ compared to $\mathrm{Fl}$ and darkness treatments. Then, the optimum moment to harvest carrot sprouts would be after $7 \mathrm{dD}+3 \mathrm{dP}$, applying $\mathrm{B}+\mathrm{R}$ LEDs during the $16 \mathrm{~h}$ lighting/ $8 \mathrm{~h}$ darkness photoperiod, in which the best overall quality is reached. Nevertheless, if the objective is to reach an enhanced concentration of phenolic acids (neochlorogenic, chlorogenic, caffeic acid, rutin, and 1,2-disinapoyl-1'-ferulolylgentiobiose), it would be recommended to add 15\% FR to B+R LED lighting during the last three days of sprouting, although this treatment tends to decrease the carotenoid content by $59 \%$ compared to $\mathrm{B}+\mathrm{R}$. However, a high concentration of carotenoids would be more interesting since carrots are especially rich in those pigments, being a more important source when compared to other vegetable sprouts.

Supplementary Materials: The following are available online at https: / /www.mdpi.com/2073-439 5/11/2/304/s1, Figure S1: PDA spectra of identified carotenoid peaks of carrot sprouts. (1) all-trans neoxanthin, (2) 13 or 13' -cis lutein, (3) all-trans lutein, (4) 9-cis lutein, (5) 15-cis $\beta$-carotene, (6) all-trans $\beta$-carotene, and (7) 9-cis $\beta$-carotene.

Author Contributions: Conceptualization and methodology: F.A.-H., L.M.-Z. and N.C.; performed the experiments: L.M.-Z. and N.C.; investigation: F.A.-H., L.M.-Z. and N.C.; software: L.M.-Z. and N.C.; validation: F.A.-H., L.M.-Z. and N.C.; resources: F.A.-H.; data curation: L.M.-Z. and N.C.; writing—original draft preparation+review and editing: F.A.-H., L.M.-Z., N.C. and P.A.G.; visualization: F.A.-H.; supervision: F.A.-H.; project administration: F.A.-H.; funding acquisition: F.A.-H. All authors have read and agreed to the published version of the manuscript. 
Funding: Project financed by the Autonomous Community of the Region of Murcia n ${ }^{\circ}$ 20849/PI/18 through the grant call for projects for the development of scientific and technical research by competitive groups, included in the Regional Programme for the Promotion of Scientific and Technical Research (Action Plan 2018) of the Seneca Foundation-Science and Technology Agency of the Region of Murcia (Spain).

Institutional Review Board Statement: Not applicable.

Informed Consent Statement: Not applicable.

Data Availability Statement: Not applicable.

Acknowledgments: Noelia Castillejo was funded by a predoctoral grant (FPU16/04763) from the Spanish Ministry of Education. Lorena Martínez-Zamora's contract has been co-financed by the European Social Fund (ESF) and the Youth European Initiative (YEI) under the Spanish Seneca Foundation (21322/PDGI/19). The technical assistance of Francisca Andreo is highly appreciated.

Conflicts of Interest: The authors declare no conflict of interest.

\section{References}

1. Cisneros-Zevallos, L.; Jacobo-Velázquez, D.A. Controlled Abiotic Stresses Revisited: From Homeostasis through Hormesis to Extreme Stresses and the Impact on Nutraceuticals and Quality during Pre- and Postharvest Applications in Horticultural Crops. J. Agric. Food Chem. 2020, 11877-11879. [CrossRef] [PubMed]

2. Pennisi, G.; Blasioli, S.; Cellini, A.; Maia, L.; Crepaldi, A.; Braschi, I.; Spinelli, F.; Nicola, S.; Fernandez, J.A.; Stanghellini, C.; et al. Unraveling the role of red:Blue LED lights on resource use efficiency and nutritional properties of indoor grown sweet basil. Front. Plant Sci. 2019, 10, 305. [CrossRef] [PubMed]

3. Pennisi, G.; Orsini, F.; Blasioli, S.; Cellini, A.; Crepaldi, A.; Braschi, I.; Spinelli, F.; Nicola, S.; Fernandez, J.A.; Stanghellini, C.; et al. Resource use efficiency of indoor lettuce (Lactuca sativa L.) cultivation as affected by red:blue ratio provided by LED lighting. Nat. Sci. Rep. 2019, 9, 14127. [CrossRef]

4. Cisneros-Zevallos, L. The use of controlled postharvest abiotic stresses as a tool for enhancing the nutraceutical content and adding-value of fresh fruits and vegetables. J. Food Sci. 2003, 68, 1560-1565. [CrossRef]

5. Bliznikas, Z.; Žukauskas, A.; Samuoliene, G.; Viršile, A.; Brazaityte, A.; Jankauskiene, J.; Duchovskis, P.; Novičkovas, A. Effect of supplementary pre-harvest LED lighting on the antioxidant and nutritional properties of green vegetables. Acta Hortic. 2012, 939, 85-91. [CrossRef]

6. Chen, M.; Chory, J.; Fankhauser, C. Light signal transduction in higher plants. Annu. Rev. Genet. 2004, 38, 88-117. [CrossRef]

7. Chen, M.; Chory, J. Phytochrome signaling mechanisms and the control of plant development. Trends Cell Biol. 2011, 21, 664-671. [CrossRef]

8. Chen, M.; Blankenship, R.E. Expanding the solar spectrum used by photosynthesis. Trends Plant Sci. 2011, 16, 426-431. [CrossRef]

9. Huché-Thélier, L.; Crespel, L.; Le Gourrierec, J.; Morel, P.; Sakr, S.; Leduc, N. Light signaling and plant responses to blue and UV radiations-Perspectives for applications in horticulture. Environ. Exp. Bot. 2016, 121, 22-38. [CrossRef]

10. Ohtake, N.; Ishikura, M.; Suzuki, H.; Yamori, W.; Goto, E. Continuous irradiation with alternating red and blue light enhances plant growth while keeping nutritional quality in lettuce. HortScience 2018, 53, 1804-1809. [CrossRef]

11. Kwack, Y.; Kim, K.K.; Hwang, H.; Chun, C. Growth and quality of sprouts of six vegetables cultivated under different light intensity and quality. Hortic. Environ. Biotechnol. 2015, 56, 437-443. [CrossRef]

12. Galieni, A.; Falcinelli, B.; Stagnari, F.; Datti, A.; Benincasa, P. Sprouts and microgreens: Trends, opportunities, and horizons for novel research. Agronomy 2020, 10, 1424. [CrossRef]

13. Nam, T.G.; Kim, D.O.; Eom, S.H. Effects of light sources on major flavonoids and antioxidant activity in common buckwheat sprouts. Food Sci. Biotechnol. 2018, 27, 169-176. [CrossRef]

14. Seo, J.M.; Arasu, M.V.; Kim, Y.B.; Park, S.U.; Kim, S.J. Phenylalanine and LED lights enhance phenolic compound production in Tartary buckwheat sprouts. Food Chem. 2015, 117, 204-213. [CrossRef]

15. Arscott, S.A.; Tanumihardjo, S.A. Carrots of many colors provide basic nutrition and bioavailable phytochemicals acting as a functional food. Compr. Rev. Food Sci. Food Saf. 2010, 9, 223-239. [CrossRef]

16. Que, F.; Hou, X.L.; Wang, G.L.; Xu, Z.S.; Tan, G.F.; Li, T.; Wang, Y.H.; Khadr, A.; Xiong, A.S. Advances in research on the carrot, an important root vegetable in the Apiaceae family. Hortic. Res. 2019, 6, 1-15. [CrossRef]

17. Singleton, V.L.; Rossi, J.A.J. Colorimetry of total phenolics with phosphomolybdic-phosphotungstic acid reagents. Am. J. Enol. Vitic. 1965, 16, 144-158.

18. Moreira-Rodríguez, M.; Nair, V.; Benavides, J.; Cisneros-Zevallos, L.; Jacobo-Velázquez, D.A. UVA, UVB light, and methyl jasmonate, alone or combined, redirect the biosynthesis of glucosinolates, phenolics, carotenoids, and chlorophylls in broccoli sprouts. Int. J. Mol. Sci. 2017, 18, 2330. [CrossRef] 
19. Castillejo, N.; Martínez-Hernández, G.B.; Monaco, K.; Gómez, P.A.; Aguayo, E.; Artés, F.; Artés-Hernández, F. Preservation of bioactive compounds of a green vegetable smoothie using short time-high temperature mild thermal treatment. Food Sci. Technol. Int. 2017, 23, 46-60. [CrossRef] [PubMed]

20. Castillejo, N.; Martínez-Zamora, L.; Gómez, P.A.; Pennisi, G.; Crepaldi, A.; Fernández, J.A.; Orsini, F.; Artés-Hernández, F. Postharvest Led Lighting: Effect of Red, Blue, and Far Red on Quality Of Minimally Processed Broccoli Sprouts. J. Sci. Food Agric. 2020, 101, 44-53. [CrossRef] [PubMed]

21. Gupta, P.; Sreelakshmi, Y.; Sharma, R. A rapid and sensitive method for determination of carotenoids in plant tissues by high performance liquid chromatography. Plant Methods 2015, 11, 1-12. [CrossRef]

22. Ainsworth, E.A.; Gillespie, K.M. Estimation of total phenolic content and other oxidation substrates in plant tissues using Folin-Ciocalteu reagent. Nat. Protoc. 2007, 2, 875-877. [CrossRef]

23. Georgé, S.; Brat, P.; Alter, P.; Amiot, M.J. Rapid determination of polyphenols and vitamin C in plant-derived products. J. Agric. Food Chem. 2005, 53, 1370-1373. [CrossRef] [PubMed]

24. Parks, B.M.; Hoecker, U.; Spalding, E.P. Light-induced growth promotion by SPA1 counteracts phytochrome-mediated growth inhibition during de-etiolation. Plant Physiol. 2001, 126, 1291-1298. [CrossRef]

25. Parks, B.M.; Spalding, E.P. Sequential and coordinated action of phytochromes A and B during Arabidopsis stem growth revealed by kinetic analysis. Proc. Natl. Acad. Sci. USA 1999, 96, 14142-14146. [CrossRef]

26. Folta, K.M.; Spalding, E.P. Unexpected roles for cryptochrome 2 and phototropin revealed by high-resolution analysis of blue light-mediated hypocotyl growth inhibition. Plant J. 2001, 26, 471-478. [CrossRef] [PubMed]

27. Wang, Y.; Folta, K.M. Contributions of green light to plant growth and development. Am. J. Bot. 2013, 100, 70-78. [CrossRef] [PubMed]

28. Kuno, Y.; Shimizu, H.; Nakashima, H.; Miyasaka, J.; Ohdoi, K. Effects of irradiation patterns and light quality of red and blue light-emitting diodes on growth of leaf lettuce (Lactuca sativa L."Greenwave"). Environ. Control Biol. 2017, 55, 129-135. [CrossRef]

29. Park, C.H.; Kim, N.S.; Park, J.S.; Lee, S.Y.; Lee, J.W.; Park, S.U. Effects of light-emitting diodes on the accumulation of glucosinolates and phenolic compounds in sprouting canola (Brassica napus L.). Foods 2019, 8, 76. [CrossRef]

30. Liu, H.K.; Chen, Y.Y.; Hu, T.T.; Zhang, S.J.; Zhang, Y.H.; Zhao, T.Y.; Yu, H.E.; Kang, Y.F. The influence of light-emitting diodes on the phenolic compounds and antioxidant activities in pea sprouts. J. Funct. Foods 2016, 25, 459-465. [CrossRef]

31. Qian, H.; Liu, T.; Deng, M.; Miao, H.; Cai, C.; Shen, W.; Wang, Q. Effects of light quality on main health-promoting compounds and antioxidant capacity of Chinese kale sprouts. Food Chem. 2016, 196, 1232-1238. [CrossRef] [PubMed]

32. Huang, J.; Xu, Y.; Duan, F.; Du, X.; Yang, Q.; Zheng, Y. Improvement of the Growth and Nutritional Quality of Two-leaf-color Pak Choi by Supplemental Alternating Red and Blue Light. HortScience 2020, 1, 118-125. [CrossRef]

33. Hossen, M.Z. Light emitting diodes increase phenolics of buckwheat (Fagopyrum esculentum) sprouts. J. Plant Interact. 2007, 2, 71-78. [CrossRef]

34. Bae, J.H.; Park, S.Y.; Oh, M.M. Growth and phenolic compounds of Crepidiastrum denticulatum under various blue light intensities with a fixed phytochrome photostationary state using far-red light. Hortic. Environ. Biotechnol. 2019, 60, 199-206. [CrossRef]

35. Rodriguez-Concepcion, M.; Stange, C. Biosynthesis of carotenoids in carrot: An underground story comes to light. Arch. Biochem. Biophys. 2013, 539, 110-116. [CrossRef]

36. Frede, K.; Schreiner, M.; Baldermann, S. Light quality-induced changes of carotenoid composition in pak choi Brassica rapa ssp. chinensis. J. Photochem. Photobiol. B Biol. 2019, 193, 18-30. [CrossRef]

37. Brazaitytè, A.; Sakalauskienè, S.; Samuolienè, G.; Jankauskienè, J.; Viršilè, A.; Novičkovas, A.; Sirtautas, R.; Miliauskienė, J.; Vaštakaite, V.; Dabašinskas, L.; et al. The effects of LED illumination spectra and intensity on carotenoid content in Brassicaceae microgreens. Food Chem. 2015, 173, 600-606. [CrossRef]

38. Zhang, X.; Bian, Z.; Yuan, X.; Chen, X.; Lu, C. A review on the effects of light-emitting diode (LED) light on the nutrients of sprouts and microgreens. Trends Food Sci. Technol. 2020, 99, 203-216. [CrossRef] 